\title{
REPOSISI KEDUDUKAN JANDA (CERAI MATI) DALAM HUKUM WARIS ADAT BATAK DALAM PERSPEKTIF GENDER
}

\author{
STANDING repositioning WIDOW (DIVORCE OFF) BATAK CUSTOMARY LAW INHERITANCE \\ OF GENDER PERSPECTIVE
}

\author{
Amri P Sihotang, Endah P A, A.Heru N \\ Fakultas Hukum Universitas Semarang
}

\begin{abstract}
ABSTRAK
Tulisan ini mengkaji tentang reposisi kedudukan janda (cerai mati) dalam hukum waris adat Batak dengan pendekatan gender. Hukum waris adat Batak, masih cenderung merujuk pada sistem kekerabatan patrilineal, yaitu sistem kekerabatan yang ditarik menurut garis bapak, dimana janda (cerai mati) bukanlah ahli waris dari suaminya, karena yang menjadi ahli waris pada masyarakat Batak hanya anak laki-laki. Dengan perkembangan zaman dan semakin besarnya peran seorang ibu/ wanita dalam rumah tangga, maka perlu dikaji lebih mendalam materi kedudukan seorang ibu/ wanita yang ditinggal mati suaminya (janda cerai mati) dalam hukum waris adat Batak dengan berbagai pendekatan, salah satunya dengan pendekatan gender. Hal tersebut penting dilakukan, karena telah banyak pemikir modern hukum adat yang ingin melakukan pembaruan dalam hukum adat, khususnya waris demi tercapainya kesetaraan gender yang sesuai dengan perkembangan zaman, diantaranya dengan cara mereposisi kedudukan janda (cerai mati) dalam sistem pewarisan melalui pembentukan hukum adat waris nasional yang bersifat bilateral. Pembelajaran hukum waris adat Batak dengan pendekatan gender, masyarakat Batak dapat berfikir kritis dan tidak kaku dalam menyelesaikan tentang masalah pembagian warisan dengan menempatkan janda (cerai mati) sebagai ahli waris.
\end{abstract}

Kata Kunci : Reposisi, Kedudukan Janda, Hukum Waris

\section{ABSTRACT}

This writing mengkaji about widow position reposition (off divorce) in custom beneficial owner law Robs with gender's approaching. Custom beneficial owner law Robs, still tend refers on patrilineal's kinship system, which is cold-drawn kinship system terminological father lining, where are widow (off divorce) not heir of its husband, since one becomes heir on society just Rob boy. With epoch developing and the greater role a mother / woman in family, therefore need more been assessed visceral material domiciles a mother / woman that is stayed behind dies its husband (widow parts to die) in custom beneficial owner law Robs with approaching sort, one of it with gender's approaching. That thing essential is done, since have a lot of commons law modern thinker which want to do renewal in common law, notably beneficial owner after be reached gender's equivalence that corresponds to epoch developing, amongst those by repositions widow position (off divorce) in endowment system via formation national beneficial owner common law that gets bilateral's character. Expected by beneficial owner law learning custom Robs with gender's approaching, society Robs to get bethinks critical and not rigorous in solves about inheritance division problem by place widow (off divorce) as heir.

Keywords: Reposition, position, widow off divorce

\section{PENDAHULUAN}

Adat adalah kebiasaan suatu masyarakat yang bersifat ajeg (dilakukan terus-menerus), diper-tahankan oleh pendukungnya. Kebiasaan merupa-kan cerminan kepribadian sesuatu bangsa, ia adalah penjelmaan jiwa bangsa itu yang terusmenerus berkembang secara evolusi dari abad ke abad. Perkembangannya ada yang cepat dan ada yang lambat. Secepat apapun perkembangannya, namun tidak bersifat revolusioner, selalu dilandasi oleh nilai dasar yang menjadi pedoman mereka 
yang mengubah, memperbaharui atau menghilangkan sebagian dari kebiasaan itu jika kebiasaan itu sudah tidak fungsional lagi. ${ }^{1}$

Setiap bangsa atau masyarakat memiliki kebudayaannya sendiri, oleh karena itu setiap masyarakat memiliki hukumnya masing-masing yang berbeda satu sama lain. Perbedaan inilah yang menunjukkan bahwa setiap masyarakat memiliki ciri khasnya masing-masing sebagai identitas bangsa yang bersangkutan seperti kearifan lokal. Dalam hal ini, hukum adat adalah aturan kebiasaan manusia dalam hidup bermasyarakat. Jadi adat adalah kebiasaan masyarakat dan kelompok, dari masyarakat menjadikannya sebagai adat yang seharusnya dilaksanakan dan berlaku untuk seluruh masyarakat tersebut, sehingga menjadi hukum adat. ${ }^{2}$

Dalam bidang hukum waris misalnya, tiap daerah berbeda-beda, ada yang menganut hukum waris BW (perdata) dan hukum waris Islam. Hukum waris adat dalam hal ini menunjukkan corak yang khas dari aliran pikiran budaya Indonesia dan bersendi atas prinsip yang timbul dari aliran-aliran pikiran komunal serta konkret bangsa Indonesia. Oleh sebab itu, hukum waris adat memperlihatkan perbedaan yang prinsipil dengan hukum waris BW (perdata) dan hukum waris Islam.

Apabila kita membahas tentang hukum waris adat, maka kita tidak akan bisa terlepas dari sistem kekerabatan (kekeluargaan), karena dengan sistem kekerabatan, kita dapat mengetahui siapa yang berhak mendapat harta warisan, termasuk istri yang ditinggal mati oleh suaminya (janda cerai mati). Secara teoritis, sistem kekerabatan dapat dibedakan dalam tiga corak, yaitu:

1. Sistem patrilineal, yaitu sistem kekerabatan yang ditarik menurut garis bapak, dimana kedudukan pria lebih menonjol pengaruhnya dari pada kedudukan wanita didalam pewarisan. Sistem ini terdapar di Gayo, Alas, Batak, Nias, Lampung, Buru, Seram, Nusa Tenggara, dan Irian;

2. Sistem matrilineal, yaitu sistem kekerabatan yang ditarik menurut garis ibu, dimana kedudukan wanita lebih menonjol pengaruhnya dari kedudukan pria didalam pewarisan. Sistem ini terdapat di Minangkabau, Enggano, dan Timor;

3. Sistem parental atau bilateral, yaitu sistem kekerabatan yang ditarik menurut garis dua

1 Dominikus Rato, Pengantar Hukum Adat, (Yogyakarta: Laksbang Pressindo, Yogyakarta, 2009), halaman 1.

2 Hilman Hadikusuma, Pengantar Ilmu Hukum Adat Indonesia, (Bandung: Mandar Maju, 2003), halaman 1. sisi (bapak-ibu), dimana kedudukan pria dan wanita tidak dibedakan didalam pewarisan. Sistem ini terdapat di Aceh, Sumatera Timur, Riau, Jawa, Kalimantan, dan Sulawesi. ${ }^{3}$

Masyarakat Batak merupakan salah satu dari sekian banyak masyarakat hukum adat yang ada di Indonesia. Masyarakat Batak merupakan masyarakat patrilineal murni, yang berarti setiap orang yang dalam masyarakat itu menarik garis keturunan ke atas hanya melalui penghubung lakilaki saja,sampai kepada seorang laki-laki yang merupakan moyang asal mereka. ${ }^{4}$ Hanya anak laki-laki yang menjadi ahli waris, karena anak perempuan di luar dari golongan patrilinialnya semula, sesudah mereka itu kawin. ${ }^{5}$ Selain itu, seorang janda bukan sebagai ahli waris suaminya dalam hukum adat Batak. J.C. Vergouwen dalam hal ini mengatakan bahwa:

Hak menggantikan menurut alur laki-laki secara langsung terwujud melalui kelahiran anak lelaki, ia adalah pelaksanaan wajar dari kesinambungan keturunan laki-laki dari alur bapak.

Bias gender sangat tampak dalam sistem pewarisan masyarakat Batak. Padahal adanya emansipasi wanita telah menyebabkan beberapa pemikir modern hukum adat yang ingin melakukan pembaruan dalam hukum adat khususnya waris demi tercapainya kesetaraan gender dalam pewarisan yang sesuai dengan perkembangan zaman. Adanya pengaruh gender dan emansipasi wanita, ada tuntutan dari para masyarakat Batak untuk memperbaruhi hukum adat mereka, khususnya masalah kewarisan dan salah satunya adalah masalah pembagian warisan dengan menempatkan janda (cerai mati) sebagai ahli waris.

Menurut Undang-Undang No.1 Tahun 1974 tentang Perkawinan, pada Pasal 38 menyebutkan: Perkawinan dapat putus karena; (a). Perceraian, (b). Kematian, (c). Atas Keputusan Pengadilan. Pada masyarakat Batak yang merupakan masyarakat patrilineal murni, apabila putusnya perkawinan disebabkan karena perceraian, maka sebelumnya akan diadakan suatu rapat, yaitu rapat hasirangan, dimana dalam rapat itu bertujuan untuk menetukan siapa yang bersalah dan akan dibicarakan mengenai harta bersama. Tetapi

3 I. Gede Ab. Wiranata, Hukum Adat di Indonesia, (Bandung: PT. Citra Aditya Bakti, 2005), halaman15-17

${ }^{4}$ Zainuddin Ali, Pelaksanaan Hukum Waris di Indonesia, (Jakarta: Sinar Grafika, 2008), halaman 25.

5 Eman Suparman, Hukum Waris Indonesia, (Bandung: Refika Aditama, 2005), halaman 44. 
apabila putusnya perkawinan disebabkan oleh kematian, maka timbullah persoalan waris dan pemeliharaan atas anak.

Ketentuan tersebut tentu saja dirasakan tidak adil, karena di dalam suatu perkawinan hubungan lahir maupun bathin antara suami dengan istrinya itu sudah sedemikian eratnya, bahkan jauh melebihi hubungan antara suami dan para keluarga sedarahnya. Menurut kalangan feminis, hukum waris adat Batak tersebut sangat bersifat patriarkat dan tak peka terhadap kedudukan dan kepentingan perempuan, sehingga mereka menuntut adanya pembaruan dalam hukum waris adat Batak.

Namun upaya pembaruan hukum waris adat Batak tersebut selalu menghadapai perlawanan yang berat, khususnya dari kelompok yang mengklaim diri sebagai pemilik otoritas hukum adat. Sebab, mengubah hukum adat dianggap membahayakan karena ia berarti mengubah esensi budaya orang Batak. Sebaliknya, mempertahankan hukum adat meskipun tidak relevan dengan kebutuhan masyarakat dipandang sebagai upaya mempertahankan hukum adat. Akibatnya, tidak semua masyarakat Batak melakukan pembaruan terhadap hukum adatnya khususnya yang menyangkut hukum waris.

Seiring dengan perkembangan jaman yang bertambah maju, dan sifat hukum adat yang dinamis, maka hal tersebut sudah banyak berubah. Pada saat ini, sudah banyak masyarakat Batak yang hidup merantau, sehingga membawa pengaruh terhadap hukum adat yang asli (tradisional). Menurut hukum adat Batak dimasa sekarang, bahwa kedudukan antara suami dan istri adalah sama dan seimbang. Suami adalah kepala keluarga dan istri adalah ibu rumah tangga. Mereka secara bersama sama berhak dan berkewajiban mengurus keluarga dan anakanaknya. Hal itu dapat terjadi karena hukum adat, (khususnya hukum waris adat) mendapat pengaruh dari perubahan-perubahan sosial dan juga peraturan-peraturan hukum lain yang oleh hakim selalu diterapkan ${ }^{6}$.

Seperti yang ditegaskan didalam UndangUndang No. 1 Tahun 1974 tentang Perkawinan, pada Pasal 31, menyebutkan:

(1). Hak dan kedudukan istri adalah seimbang dengan hak dan kedudukan suami dalam kehidupan rumah tangga dan pergaulan hidup bersama dalam masyarakat.

(2). Masing-masing pihak berhak untuk melakukan perbuatan hukum.

6 Soerojo Wignjodipoero, Pengantar dan Azas-azas Hukum Adat, (Jakarta: Gunung Agung, 1989), halaman 62.
(3). Suami adalah kepala rumah tangga dan istri ibu rumah tangga.

Sehingga apabila putusnya perkawinan disebabkan karena meninggalnya suami, maka janda berhak melanjutkan penguasaan atas harta perkawinan yang terdiri dari harta pencarian atau harta bersama (yang diperoleh dalam perkawinan) dan harta bawaan (yang diperoleh sebelum atau sesudah perkawinan berupa hadiah/pemberian anggota kerabat atau orang lain dan atau harta warisan). Selain itu, janda juga mempunyai hak memakai seumur hidup dari harta suaminya, selama harta itu diperlukan buat penghidupannya, dengan syarat janda tersebut wajib tetap berada dalam ikatan kekeluargaan kerabat suaminya, dalam arti janda tersebut tidak menikah lagi dengan orang lain

Berdasarkan berbagai uraian dalam latarbelakang sebagaimana telah dikemukakan di atas, maka pentingnya dari dilakukannya kajian ini adalah untuk mengetahui bagaimana sebenarnya kedudukan janda (cerai mati) dalam hukum waris adat Batak dan bagaimana mereposisi kedudukan janda (cerai mati) dalam hukum waris adat Batak dalam perspektif gender seiring dengan perkembangan jaman yang bertambah maju, dan sifat hukum adat yang dinamis.

Berpijak dari latar belakang sebagaimana telah diuraikan di muka, pokok permasalahan yang akan dikaji lebih lanjut dalam kajian ini dirumuskan sebagai berikut:

1. Bagaimana sebenarnya kedudukan janda (cerai mati) dalam hukum adat waris Batak?

2. Bagaimana mereposisi kedudukan janda (cerai mati) dalam hukum adat waris Batak dalam perspektif gender?

\section{TINJAUAN PUSTAKA}

\section{A. Kerangka Teori}

Bebebapa teori hukum yang dapat dijadikan sebagai landasan dan penuntun dalam melihat kemungkinan mewujudkan kodifikasi hukum kewarisan, diantaranya adalah:

1. Teori Roscoe Pound, yang berpendapat bahwa hukum adalah sarana pembaruan masyarakat atau law as a tool of social engineering. Dengan teorinya tersebut, Roscoe Pound selanjutnya menjelaskan bahwa hukum sebagai suatu lembaga sosial dapat disempurnakan melalui usaha manusia yang dilakukan secara cendekia, dan menganggap sebagai kewajiban mereka untuk menemukan cara-cara yang paling 
baik bagi memajukan serta mengarahkan usaha itu. 7

2. Teori Lawrence M. Friedman. Teori sistem hukum dari Friedman ini dapat digunakan sebagai alat analisis dalam upaya pembentukan hukum kewarisan nasional dengan sistem bilateral. Friedman menjelaskan bahwa sistem hukum memiliki tiga unsur, yaitu struktur hukum; substansi atau materi hukum; dan budaya hukum. ${ }^{8}$ Penggunaan teori Friedman, untuk mendukung teori Roscoe Pound, terutama penekanannya pada fungsi sistem hukum kewarisan sebagai kontrol sosial. Karena menurut Friedman, sistem hukum sebagai bagian dari sistem sosial menjadi kontrol sosial sehingga semua sistem yang lain kurang lebih menjadi sekunder atau berada di bawah sistem hukum. ${ }^{9}$

3. Teori Paul Scholten juga dapat dijadikan sebagai landasan dan penuntun dalam melihat kemungkinan mewujudkan kodifikasi hukum kewarisan. Teori Paul Scholten tentang kesadaran hukum disebut Rechtsgefuhl atau Rechtsbewustzijn. Menurut Paul Scholten, kesadaran hukum masyarakat adalah dasar sahnya hukum positif dan tidak ada hukum yang mengikat warga-warga masyarakat kecuali atas dasar kesadaran hukum. ${ }^{10}$ Sebagai pencetus atas teori ini, Paul Scholten selanjutnya berpendapat bahwa, kesadaran hukum adalah sumber dari semua hukum. Untuk di Indonesia faktor kesadaran hukum mendapat tempat yang sangat penting di dalam pembangunan sistem dan politik hukum, dan kesadaran hukum menjadi salah satu asas pembangunan nasional.

4. Teori Carl von Savigny. Carl von Savigny dari mazhab sejarah dan kebudayaan dalam pandangannya mengatakan, "Das Recht wird nicht gemacht, est und wird mit dem volke"11. Jadi menurut Savigny, hukum itu tidak dibuat, tetapi tumbuh dan berkembang bersama masyarakat sebagai living law. Oleh karena itu,

7 Abdurrahman, Kompilasi Hukum Islam, Cetakan I, (Jakarta: Akademika Presindo, 1992), halaman 19.

${ }^{8}$ Lawrence Meir Friedman, American Law: an Introduction, Edisi Kedua, Terj. Wishnu Basuki dengan judul, Hukum Amerika: Sebuah Pengantar, Cetakan I, 2001, (Jakarta: PT Tatanusa, 2001), halaman 7-8.

${ }^{9}$ Friedman, ibid., halaman 8 .

${ }^{10}$ Soerjono Soekanto dan Mustafa Abdullah, Sosiologi Hukum dalam Masyarakat, Cetakan I, (Jakarta: , CV Rajawali, 1980), halaman 338.

${ }^{11}$ Lili Rasyidi dan Ira Thania Rasyidi, Dasardasar Filsafat dan Teori Hukum, Cetakan IX, (Bandung: PT Citra Aditya Bakti, 2004), halaman 65. hukum yang baik adalah hukum yang hidup dan tumbuh dalam masyarakat, serta menjadi pedoman bagi anggota masyarakat dalam berperilaku.

Teori Savigny dikembangkan di Indonesia oleh Soepomo dengan mengambil hukum adat sebagai standar. Menurut Soepomo, hukum adat adalah suatu hukum yang hidup, karena ia menjelmakan perasaan hukum yang nyata dari rakyat serta bersifat dinamis dan tumbuh berkembang sejalan dengan perkembangan masyarakatnya. ${ }^{12}$

Hukum waris adat adalah hukum adat yang memuat garis-garis ketentuan tentang sistem dan asas-asas hukum waris, tentang harta warisan, pewaris dan cara harta warisan itu dialihkan.

\section{B. Undang-undang yang mengatur Diskriminasi Perempuan}

a. Amanat konvensi dan Undang-Undang No. 7 Tahun 1984 telah jelas menghapuskan segala bentuk diskriminasi, dengan mengedepankan asas persamaan dalam hukum (eguality), dengan pengertian juga dalam adat sebagai hukum yang tidak tertulis. Asas mana telah diterima di seluruh dunia sebagai asas yang berlaku universal. Tidak hanya itu, asas keadilan sesungguhnya mengilhami asas persamaan, dengan demikian kita akan mampu melihat diskrimasi itu bukan merupakan takdir yang tidak bisa dilawan kaum perempuan.

b. Convention the Elimination of All Forms of Discrimination against Women, tanggal 18 Desember 1979, yang diratifikasi oleh Indonesia dengan dikeluarkannya UndangUndang No. 7 Tahun 1984 tentang Pengesahan Konvensi Mengenai Penghapusan Segala Bentuk Diskriminasi Terhadap Wanita. Dalam Pasal 2 disebutkan "Negara peserta konvensi mengutuk diskriminasi terhadap wanita dalam segala bentuknya dan bersepakat untuk menjalankan dengan segala cara yang tepat dan tanpa ditunda-tunda, kebijaksanaan menghapus diskriminasi terhadap wanita, dan untuk tujuan itu berusaha: (a) mencantumkan asas persamaan antara pria dan wanita dalam Undang-Undang Dasar Nasional mereka atau perundang-undangan yang tepat lainnya, jika belum termasuk di dalamnnya dan untuk menjamin realisasi praktis dari asas ini, melalui hukum dan cara-cara lain yang tepat; (b) membuat peraturan perundang-undangan yang tepat dan peraturan lainnya termasuk sanksi-sanksinya dimana perlu, melarang

12 Soepomo, Sistem Hukum di Indonesia Sebelum Perang Dunia II, Cetakan XV, (Jakarta: PT. Pradnya Paramita, 1997), halaman 7. 
semua diskriminasi terhadap wanita; (c) membuat peraturan-peraturan yang tepat untuk menghapus perlakuan diskriminasi terhadap wanita oleh setiap orang, organisasi atau perusahaan; (d) membuat peraturanperaturan yang tepat, termasuk pembuatan undang-undang, peraturan-peraturan, kebiasaan-kebiasaan, dan praktik-praktik yang diskriminatif terhadap perempuan".

c. Undang-Undang No. 39 Tahun 1999 Tentang Hak Asasi Manusia, Pasal 51 ayat (1) "seorang istri selama dalam ikatan perkawinan mempunyai hak dan tanggung jawab yang sama dengan suaminya atas semua hal yang berkenan dengan kehidupan perkawinannya, hubungan dengan anak-anaknya, dan hak pemilikan serta pengelolaan harta bersama"; ayat (2) "setelah putusnya perkawinan, seorang wanita mempunyai hak dan tanggung jawab yang sama dengan mantan suaminya atas semua hal yang berkenan dengan anakanaknya, dengan memperhatikan kepentingan terbaik bagi anak"; ayat (3) "setelah putusnya perkawinan, seorang wanita mempunyai hak dan tanggung jawab yang sama dengan mantan suaminya atas semua hal yang berkenan dengan harta bersama tanpa mengurangi hak anak, sesuai dengan ketentuan peraturan perundang-undangan”.

d. Amanat konvensi dan Undang-Undang No. 7 Tahun 1984 telah jelas menghapuskan segala bentuk diskriminasi, dengan mengedepankan asas persamaan dalam hukum (eguality), dengan pengertian juga dalam adat sebagai hukum yang tidak tertulis. Asas mana telah diterima di seluruh dunia sebagai asas yang berlaku universal. Tidak hanya itu, asas keadilan sesungguhnya mengilhami asas persamaan, dengan demikian kita akan mampu melihat diskrimasi itu bukan merupakan takdir yang tidak bisa dilawan kaum perempuan.

Dengan pengesahan Konvensi Mengenai Penghapusan Segala Bentuk Diskriminasi Terhadap Wanita dan Undang-undang Hak Asasi Manusia tersebut seharusnya para sesepuh dan penatua Batak berpikir ulang dan mengkaji asas dan prinsip yang diskriminatif itu, sehingga persamaan antara wanita dan pria dikedepankan baik dalam keluarga, adat, dan dalam semua kehidupan sosial batak. Berat memang dan bahkan dilematis jika kita membuat suatu perubahan yang sangat revolusif, bahkan tidak sedikit yang menolak ide ini. Namun, pro dan kontra kita jadikan sebagai kazanah untuk memperkaya ide pemikiran dan menemukan suatu kebenaran yang hakiki tanpa merugikan bahkan memojokkan yang lain. Semua elemen harus duduk bersama untuk membicarakannya, sehingga hasil yang dicapai memuaskan semua pihak.

\section{METODE PENELITIAN}

\section{A. Metode Pendekatan}

Metode pendekatan yang dipakai dalam penelitian ini adalah metode yuridis normatif, yaitu penelitian hukum yang dilakukan dengan cara meneliti atau mempelajari masalah dilihat dari segi aturan hukumnya, meneliti bahan pustaka atau data sekunder. ${ }^{13}$ Penulis menggunakan metode yuridis normatif dalam penelitian ini dengan maksud untuk menginventarisasi bahan hukum (mengumpulkan, mengelompokkan dan mengklarifikasi) dalam rangka meneliti konsistensi dan sinkronisasi tentang kedudukan janda (cerai mati) dalam hukum adat waris Batak.

\section{B. Spesifikasi Penelitian}

Dari segi tujuannya, penelitian ini cenderung deskriptif analitis, yaitu menggambarkan peraturan perundangan yang berlaku dikaitkan dengan teori-teori hukum dan praktek pelaksanaan hukum positif ${ }^{14}$, yang menyangkut permasalahan di atas. Deskriptif dalam penelitian ini maksudnya untuk memberikan gambaran secara rinci, sistematis dan menyeluruh mengenai segala hal, yang berkaitan kedudukan janda (cerai mati) dalam hukum waris adat Batak dan reposisi kedudukan janda (cerai mati) dalam hukum waris adat Batak dalam perspektif gender, sedangkan analitis mengandung makna mengelompokkan, menghubungkan, menjelaskan dan memberi makna pada pokok permasalahan yang akan dianalisis sehingga dapat memberikan gambaran yang jelas terhadap permasalahan tersebut.

\section{Sumber Data}

Jenis data yang digunakan dalam penelitian ini adalah data sekunder, mengingat penelitian ini menggunakan pendekatan hukum normatif, maka sumber data utama adalah data sekunder. Data sekunder di bidang hukum (dipandang dari sudut kekuatan mengikatnya) dapat dibedakan menjadi:

a. Bahan hukum primer, yaitu bahan hukum yang terdiri atas peraturan perundangan,

13 Soejono dan H. Abdurahman, Metode Penelitian Hukum, (Jakarta: Rineka Cipta, 2003), halaman 56.

${ }^{14}$ Moch Nazir, Metode Penelitian, (Jakarta: Ghalia Indonesia, 2008), halaman 84. 
risalah resmi, putusan pengadilan dan dokumen resmi negara.

b. Bahan hukum sekunder, yaitu bahan hukum yang terdiri atas buku atau jurnal hukum yang berisi mengenai prinsip-prinsip dasar (asas hukum), hasil penelitian hukum, kamus hukum dan ensiklopedia hukum.

\section{Metode Pengumpulan Data}

Dalam penelitian ini, data sekunder tersebut di atas diperoleh dengan cara studi kepustakaan (library research). Studi kepustakaan adalah penelitian yang dilakukan dengan cara mencari konsepsi-konsepsi, teori-teori, pendapat pendapat ataupun penemuan-penemuan hukum ${ }^{15}$, yang berhubungan erat dengan pokok permasalahan.

\section{E. Metode Analisis Data}

Metode analisis data adalah tahap yang penting dalam menentukan suatu penelitian. Analisis data dalam suatu penelitian adalah menguraikan atau memecahkan masalah yang diteliti berdasarkan data yang diperoleh kemudian diolah ke dalam pokok permasalahan yang diajukan terhadap penelitian yang bersifat deskriptif. ${ }^{16}$

Metode analisis data yang dipergunakan dalam penelitian ini adalah metode analisis deskriptif kualitatif, yaitu cara menganalisa data dengan mendeskripsikan dan menganalisis materi isi dan keabsahan data yang diperoleh dari hasil studi kepustakaan, sehingga diperoleh gambaran tentang suatu peristiwa dalam masyarakat, dalam hal ini adalah tentang kedudukan janda (cerai mati) dalam hukum waris adat Batak dan reposisi kedudukan janda (cerai mati) dalam hukum waris adat Batak dalam perspektif gender.

\section{HASIL PENELITIAN DAN PEMBAHASAN}

\section{Kedudukan Janda (Cerai Mati) dalam Hukum Waris Adat Batak}

a. Kedudukan Janda menurut Hukum Adat

Kedudukan janda sebagai ahli waris atau bukan, dipengaruhi oleh sistem kekerabatan dan bentuk perkawinan yang berlaku didalam masyarakat yang bersangkutan. Ada janda yang karena meninggalnya suami, maka tetap tidak bebas untuk menentukan sikap tindaknya, karena masih harus berkedudukan ditempat pihak kerabat suami, tetapi ada juga

15 Suharsimi Arikunto, Prosedur Penelitian Suatu Pendekatan Praktek, (Jakarta: Rineka Cipta, 2008), halaman 109.

16 Heribertus Sutopo, Pengantar Penelitian Kualitatif, (Surakarta: Puslitbang UNS, 2008), halaman 8. janda yang setelah meninggalnya suami, dapat kembali pada kerabat asalnya dan bebas menentukan sikap tindaknya. ${ }^{17}$

Kedudukan janda di dalam hukum adat terhadap harta peninggalan, bertitik tolak dari asas bahwa wanita sebagai orang asing tidak berhak mewaris. ${ }^{18}$ Hal ini terjadi apabila yang dijadikan syarat untuk mewaris adalah tali kekeluargaan berdasarkan atas persamaan darah atau keturunan, tetapi ada kenyataan, bahwa dalam suatu perkawinan itu, hubungan lahir maupun bathin antara suami dengan istrinya itu sedemikian eratnya, bahkan jauh melebihi hubungan antara suami dengan saudara kandungnya sendiri. Oleh sebab itu, di dalam rumusan kewarisan hak-hak janda harus diperhatikan, antara lain:

1). Janda berhak atas jaminan nafkah seumur hidupnya, dari hasil barang gono-gini maupun dari hasil barang asal suami.

2). Janda berhak menguasai harta peninggalan suaminya, untuk menarik penghasilan dari barang-barang itu, terlebih jika mempunyai anak, harta itu tetap merupakan kesatuan di bawah asuhan janda dan tidak dibagi-bagi.

3). Janda berhak menahan barang-barang asal suaminya, selama barang itu diperlukan olehnya, untuk keperluan nafkahnya.

4). Janda berhak mendapat bagian atau menuntut sebesar bagian anak, di dalam keadaan terpaksa diadakan pembagian dengan anak, misalnya janda hamil atau anak meminta sebagian untuk modal usaha $^{19}$.

Patut diperhatikan bahwa harus ada dua syarat, agar janda mendapatkan kedudukan sebagai ahli waris:

1). Janda harus telah lama hidup bersama dan mengikuti suka duka dalam keluarga

2). Janda, sesudah suami meninggal tidak menunjukkan sikap atau cenderung memutuskan hubungan dengan keluarga suami, juga tidak menikah lagi dengan laki-laki lain. ${ }^{20}$

${ }^{17}$ H. Hilman Hadikusuma, Hukum Waris Adat, PT. Citra Aditya Bakti Cetakan VII, Bandung, 2003.

18 Iman Sudiyat, Hukum Adat Sketsa Asas, Liberty Cetakan VII, Yogyakarta, 1981.

19 Muhammad Busar, Pokok-Pokok Hukum Adat, Pradnya Paramita Cetakan III, Jakarta, 1985.

${ }^{20}$ Ibid., hlm., 45 
Di Indonesia, terdapat 3 (tiga) bentuk sistem kekerabatan, yang sedikit banyak memberi pengaruh terhadap kedudukan janda.

\section{1). Janda dalam Sistem Patrilineal}

Masyarakat patrilineal di Batak, terikat pada sistem patrilineal yang mutlak bersifat genealogis, yaitu menarik garis keturunan dari pihak ayah. Corak utama dari masyarakat patrilineal ini, adalah perkawinan dengan Jujur. Pemberian Jujur ini oleh pihak laki-laki kepada pihak perempuan adalah sebagai lambang diputuskannya hubungan kekeluargaan si istri dengan kerabatnya dan masuk ke dalam kerabat suaminya.

\section{2). Janda dalam Sistem Matrilineal}

Sistem garis keturunan matrilineal adalah yang menghitung hubungan kekerabatan melalui perempuan saja, dan hal itu mengakibatkan tiap individu masuk dalam kerabat ibunya.

\section{3). Janda dalam Sistem Parental}

Masyarakat Jawa adalah masyarakat yang mempunyai sistem kekerabatan parental/ bilateral, yaitu setiap individu menarik garis keturunannya keatas melalui garis ayah dan ibu secara serentak atau bersamaan. Menurut hukum adat Jawa, para ahli waris dapat digolongkan dalam urutan sebagai berikut:

a). Keturunan pewaris.

b). Orangtua pewaris.

c). Saudara-saudara pewaris/keturunannya.

d). Orangtua dari orangtua pewaris. ${ }^{21}$

Di dalam urutan tersebut belum termasuk janda, walaupun pada kenyataannya, mereka adalah ahli waris juga. Hal ini adalah lanjutan dari sistem kewarisan bilateral yang menempatkan kedudukan yang sama antara laki-laki dengan perempuan sehingga memberi kedudukan yang sama pula terhadap janda untuk mewarisi harta peninggalan almarhum suaminya. ${ }^{22}$

\section{b. Kedudukan Janda (Cerai Mati) dalam Hukum Waris Adat Batak}

Perkawinan merupakan suatu peristiwa yang sangat penting dalam kedidupan di masyarakat, sebab perkawinan itu tidak hanya menyangkut laki-laki dan perempuan yang akan menjadi mempelai, tetapi juga orangtua kedua belah pihak, saudara-saudara, bahkan

${ }^{21}$ Hadikusuma, op.cit.

22 M. Yahya Harahap, Kedudukan Janda, Duda dan Anak Angkat Dalam Hukum Adat, Citra Aditya Bakti Cetakan 1, Jakarta, 1993. kerabat yang jauh sekalipun. Dengan adanya perkawinan, akan terbentuklah suatu keluarga yang baru yang merupakan kesatuan hidup yang terdiri dari ayah, ibu, anak-anak yang kemudian dipimpin oleh ayah sebagai kepala keluarga dan ibu sebagai kepala rumah tangga.

Di dalam kehidupan rumah tangga, suami-istri memikul kewajiban yang luhur untuk menegakkan norma-norma yang menjadi sendi dasar susunan masyarakat. Diantara suami-istri mempunyai hak dan kedudukan yang seimbang, baik dalam kehidupan rumah tangga maupun pergaulan hidup bersama dalam masyarakat. Tetapi, sejauh mana keseimbangan antara hak dan kedudukan suami-istri tersebut, masih dipengaruhi oleh sistem kekerabatan dan bentuk perkawinan yang dianut oleh suami-istri tersebut.

1). Kedudukan dalam Kaitanya dengan Sistem Kekerabatan dan Bentuk Perkawinan

Pada masyarakat patrilineal di Batak setiap orang yang dilahirkan selalu menarik garis keturunan melalui laki-laki/ayah. Anak laki-laki yang lahir selalu menarik garis keturunan melalui ayahnya, sehingga anakanak yang lahir mempunyai hubungan hukum dengan ayah dan keluarga ayah. Akibat dari prinsip keturunan ini, maka mengakibatkan kedudukan anak laki-laki menjadi penting, disebabkan anak laki-laki merupakan penerus keturunan. Dapat dikatakan anak laki-laki selamanya seklan dengan ayah dan keluarga ayahnya. Oleh sebab itu, pada masyarakat Batak yang bersistem patrilineal, tempat tinggal adalah turut ayah.

Begitu juga halnya dengan istri, dimana tempat tinggalnya tergantung pada suami (patri-lokal). Hal itu terjadi akibat dari bentuk perkawinan yang berlaku pada masyarakat ini, yaitu "perkawinan jujur". Pada perkawinan ini ada barang jujur yang diberikan pihak lakilaki kepada pihak perempuan, yang berfungsi untuk mengganti kekosongan magis yang terjadi didalam keluarga asal perempuan. Barang jujur ini penting dalam menjaga keseimbangan magis yang ada didalam keluarga asal perempuan. Dengan adanya perkawinan jujur tersebut, menimbulkan akibat bahwa istri lepas dari hak serta tanggung jawab keluarga asal dan masuk kedalam hak dan kewajiban serta tanggung jawab keluarga suaminya.

Jika perkawinan putus, maka tergantung dari penyebab putusnya perkawinan itu. Jika putusnya perkawinan disebabkan karena perceraian, maka sebelumnya akan diadakan 
suatu rapat, yaitu "rapat hasirangan", tujuan dari rapat itu adalah untuk menentukan siapa yang salah dan akan dibicarakan mengenai pembagian harta bersama. Jika ternyata rapat itu memutuskan bahwa suami yang bersalah, maka istri akan mendapatkan bagian lebih besar dari harta bersama, begitu pula sebaliknya apabila ternyata istri yang bersalah, maka suami akan mendapatkan bagian lebih besar daripada istrinya.

Apabila putusnya perkawinan disebabkan oleh kematian, maka timbullah persoalan waris dan pemeliharaan atas anak. Apabila yang meninggal adalah seorang suami, maka sangat tepat jika ibu (janda) yang melanjutkan pemeliharaan terhadap anak yang masih dibawah umur dan menguasai harta kekayaan si anak yang diperoleh sebagai warisan dari ayahnya yang telah meninggal dunia.

Dalam hal ini, janda hanya diberikan hak untuk menguasai dan menikmati harta (bukan memiliki), dan kelak pada saatnya nanti, harta itu akan menjadi milik anak laki-lakinya atau kepada keluarga almarhum suaminya bila ia menikah lagi atau tidak memiliki keturunan. Jadi jelaslah bahwa menurut kaidah adat masyarakat Batak, tidak memberi peluang kepada janda untuk mewarisi harta peninggalan suaminya. Hal ini diperkuat dengan pendapat Sulistyowati Irianto yang mengatakan:

1. Nilai-nilai dan konsep budaya mengenai perempuan dan laki-laki pada masyarakat Batak yang mencerminkan hubungan kekuasaan yang timpang antara laki-laki dan perempuan, menempatkan perempuan pada posisi yang lemah khususnya dalam hal waris.

2. Ketiadaan faktor teritorial di kota tidak menyebabkan berkurangnya keberlakuan nilai-nilai budaya yang berdampak pada lemahnya kedudukan perempuan dalam hal waris.

3. Migrasi orang Batak ke kota justru memperkokoh keberadaan aturan-aturan adat waris dalam segi-segi tertentu. Nilainilai mengenai harta pusaka yang tidak boleh dimiliki anak perempuan di tanah asal, diadopsi sedemikian rupa sehingga harta perkawinan (matrimonial property) pun dianggap tidak berhak dimiliki oleh anak perempuan di kalangan masyarakat Batak tertentu di kota.

4. Berkenaan dengan janda, adat waris lama yang tidak menempatkan janda sebagai ahli waris, masih tetap dipertahankan di kota, pada hal janda tersebut bersamasama dengan suaminya telah turut mengumpulkan harta selama hidup perkawinannya.

5. Dampak kontrol patriarkhi terhadap perempuan di kota telah menyebabkan semakin tajamnya stratifikasi sosial dan ekonomi menurut jender. ${ }^{23}$

2). Kedudukan Janda dalam Kaitannya dengan Prinsip Kewarisan dan Sistem Kewarisan

Dalam hukum waris adat, untuk menentukan ahli waris didasarkan pada prinsip kewarisan, dimana prinsip yang berlaku berbeda-beda antara masyarakat yang satu denga lainnya. Prinsip tersebut terdiri dari, prinsip umum dan prinsip khusus. Prinsip kewarisan umum adalah prinsip dimana untuk menjadi ahli waris haruslah mempunyai hubungan darah dengan pewaris, dengan kata lain bahwa ahli waris haruslah keturunan pewaris. Selain prinsip umum, juga dikenal adanya prinsip khusus yaitu untuk menjadi ahli waris tidak hanya mempunyai hubungan darah, tetapi juga harus satu klan dengan pewaris.

Pada masyarakat Batak yang merupakan masyarakat berklan, menganut kedua prinsip tersebut. Dimana untuk tampil mewaris, seseorang harus mempunyai hubungan darah dengan pewaris dan harus satu klan dengan pewaris. Sehingga di dalam masyarakat ini, yang tampil mewaris adalah anak laki-laki. Hal ini disebabkan anak laki-laki merupakan penerus keturunan atau mempertahankan klan ayah dan keluarga ayah.

Sehubungan dengan hal tersebut, apabila yang meninggal adalah suami, maka sudah jelas bahwa janda tidak dapat tampil sebagai ahli waris untuk mewarisi harta peninggalan almarhum suaminya, karena janda tidak mempunyai hubungan darah dan juga tidak satu klan dengan almarhum suaminya, melainkan satu klan dengan keluarga asalnya. Tetapi dengan dilakukannya perkawinan jujur, maka ia telah keluar dari klan keluarga asalnya. Sehingga dapat dikatakan bahwa janda bukanlah ahli waris dari almarhum suaminya.

Selain prinsip kewarisan, maka harus diperhatikan juga mengenai sistem kewarisan. Didalam hukum adat dikenal adanya 3 sistem kewarisan, yaitu:

a). Sistem kewarisan individual, yaitu suatu sistem hukum kewarisan adat dimana, harta warisan dibagikan kepada kerabat dan dapat dimiliki secara perseorangan

\footnotetext{
${ }^{23}$ Irianto,op. Cit., hlm.,2.
} 
dengan hak milik. Sistem kewarisan ini berlaku di kalangan masyarakat parental, hukum kewarisan barat (KUH Perdata), maupun di hukum kewarisan Islam.

b). Sistem kewarisan kolektif, yaitu suatu sistem hukum kewarisan adat dimana tidak memperbolehkan para ahli waris memiliki harta peninggalan secara pribadi: mereka hanya diperbolehkan untuk memakai, mengusahakan, atau mengolah dan menikmati hasilnya, (misalnya tanah dati di Ambon yang diurus oleh kepala dati, atau ganggam bauntuik di Minangkabau). Pada sistem ini, pada umumnya terdapat harta peninggalan yang berasal dari harta leluhur yang disebut harta pusaka.

c). Sistem kewarisan mayorat, yaitu suatu sistem hukum kewarisan adat dimana harta tidak terbagi dan hanya dikuasai oleh anak tertua. Terhadap harta ini hanya melekat status hak pakai serta hak mengolah dan memungut hasil. Penguasaan oleh anak tertua diikuti dengan hak dan kewajiban mengurus dan memelihara adik-adiknya (pria dan wanita) hingga mereka dapat berdiri sendiri. Misalnya di daerah Lampung, yang dikenal dengan adat pepaduan, seluruh harta peninggalan jatuh pada anak tertua laki-laki yang disebut anak punyimbang. Hal sama juga terjadi di Irian Jaya (Papua) dengan anak mayorat laki-lakinya. Di daerah Semendo Sumatera Selatan, harta peninggalan dikuasai oleh anak perempuan yang disebut dengan tunggu tubang (penunggu harta) namun didampingi dengan payung jurai sebagai mayorat wanita ${ }^{24}$.

Di antara ketiga sistem kewarisan tersebut dalam kenyataannya ada yang bersifat campuran. ${ }^{25}$ Masyarakat Batak menganut sistem kewarisan individual, dimana dalam sistem ini harta peninggalan akan dibagi kepada ahli waris sesuai dengan bagian masing-masing. Tetapi tentu saja hanya anak laki-laki yang berhak mendapatkan bagian dari harta peninggalan tersebut. Jika ternyata didalam keluarga itu tidak memiliki anak lakilaki, maka harta warisan jatuh kepada saudara laki-laki pewaris, yang dalam bahasa Batak dikenal dengan istilah "manean" atau "teanteanan", saudara laki-laki inilah yang dinamakan "panean" atau "manean". Apabila saudara laki-laki dari pewaris tidak ada, maka

\footnotetext{
${ }^{24}$ Hadikusuma, op.cit., hlm.,212-213.

${ }^{25}$ Hadikusuma, ibid.
}

harta warisan jatuh kepada keluarga dekat pewaris, yang ditarik menurut garis ayah.

Jadi, jelaslah bahwa jika kedudukan janda dikaitkan dengan sistem kewarisan dan prinsip kewarisan, maka dapat dikatakan bahwa janda tidak dapat mewarisi harta peninggalan suaminya, karena janda bukanlah ahli waris dari almarhum suaminya.

\section{3). Kedudukan Janda terhadap Harta Peninggalan Suami dalam Prinsip Keadilan}

Seorang janda didalam masyarakat patrilineal di Batak, setelah meninggalnya suami, mempunyai hak untuk menikmati seluruh harta pencaharian dan harta-harta lain yang dibawa oleh suami-istri kedalam perkawinan, selama janda itu tidak kawin lagi dan masih tetap tinggal dalam keluarga almarhum suaminya. Tetapi biasanya, seorang janda apabila mempunyai seorang anak lakilaki yang telah kawin, maka kewajiban anak itu untuk membelanjai dan memelihara janda tersebut.

Apabila terjadi pembagian warisan dan anak laki-lakinya tidak mungkin untuk membelanjai atau memelihara janda tersebut, maka sebagian dari harta alamarhum suaminya itu harus ditinggalkan dan diserahkan kepada janda tersebut untuk bekal hidupnya. Seandainya janda tersebut meninggal dunia, maka harta tersebut dibagi lagi oleh para ahli waris atau apabila sebelumnya, telah ditentukan untuk dikuasai janda tersebut, maka ahli waris tersebut baru dapat menguasai bagian itu, apabila janda telah meninggal, para ahli waris tidak berhak mengganggu hak janda.

Hak menikmati tersebut terbatas hanya pada hal-hal yang perlu dan layak untuk penghidupan janda. Tetapi untuk menjual barang-barang yang merupakan harta peninggalan almarhum suami, harus mendapat persetujuan dari keluarga dekat/ahli waris lainnya. Menurut hukum adat Batak, janda bukan ahli waris terhadap harta peninggalan suami, tetapi janda hanya berfungsi sebagai:

a). Pengawas atau pemelihara harta peninggalan, menggantikan kedudukan suami yang telah meninggal guna menjaga kepentingan ahli waris.

b). Selama janda masih hidup, maka berhak menguasai dan menikmati harta-harta tersebut serta berhak atas hasil dan keuntungan yang timbul dari usaha itu.

c). Sifat pengawasan dan penikmatan tadi tidak boleh mengurangi atau memisahkan maupun menjual harta-harta tersebut. Penjualan hanya dapat dilakukan jika 
telah mendapat persetujuan ahli waris lainnya ${ }^{26}$.

Akan tetapi perlu diingat, bahwa pengawasan dan penikmatan itu akan hilang dengan sendirinya, apabila janda itu telah keluar dari keluarga almarhum suaminya atau janda tersebut melakukan perkawinan dengan laki-laki lain diluar kerabat almarhum suaminya.

4). Bagian-Bagian Janda dalam Waris Adat Batak dalam Prinsip Keadilan

Janda di daerah Batak dalam bentuk perkawinan memakai jujur setelah wafat suaminya tetap berkedudukan ditempat kerabat suami, ia tetap berhak menikmati harta kekayaan yang ditinggalkan suami, walaupun ia bukan waris dari suaminya. Di tanah Batak, janda bukan waris dari suaminya, tetapi mereka selama hidupnya berhak pakai atas harta suami dalam batas kebutuhan penghidupannya. Hal mana dapat dilihat dari beberapa Keputusan Pengadilan sebagai berikut:

Menurut Keputusan Pengadilan Negeri Tapanuli Selatan tanggal 12 Desember 1953 No.81/1953/SHP.Ps, dikatakan bahwa menurut hukum adat di daerah Batak seorang janda perempuan tidak dapat mewaris tanahtanah tinggalan suaminya. Kemudian Keputusan Pengadilan Tinggi Medan tanggal 23 April 1957 No.50/1954 dikatakan, menurut hukum adat Batak seorang janda perempuan tidak dapat mewaris tanah-tanah tinggalan suaminya, tetapi dapat menuntut agar tetap menikmati tanah-tanah tinggalan suaminya itu, selama harta itu diperlukan buat penghidupannya.

Apabila janda dalam sistem patrilineal bukan merupakan ahli waris dari suami, tetapi merupakan penghubung atau jembatan pewarisan dari ayah kepada anak-anaknya yang lelaki, maka begitu juga sebenarnya suami bukan waris dari istrinya yang wafat, karena menurut alam fikiran dalam sistem kekerabatan ini istri adalah milik suami, apalagi harta bawaan dan harta pencaharian yang selama perkawinan merupakan satu kesatuan yang tidak terpisah dan tidak terbagibagi kedudukannya ${ }^{27}$.

Dari harta peninggalan suaminya, istri tidak mendapat bagian sebagai waris, melainkan hak menarik penghasilan dari harta tersebut seumur hidup, jika perlu. Untuk

\footnotetext{
${ }^{26}$ Soekanto dan Usman, op.cit.

${ }^{27}$ Hadikusuma, op.cit., hlm.,212-213.
}

nafkah itu, istri (janda) dapat pula diberi bagian yang layak sekaligus dari harta peninggalan suaminya, hal mana sering terjadi apabila anak-anaknya semua sudah dewasa dan mentas serta mencar (tidak serumah lagi). Janda berhak mandapat nafkah seterusnya, sehingga untuk keperluan itu kadang-kadang harta peninggalan dibiarkan padanya tak dibagi-bagi, termasuk juga barang asal suaminya.

\section{Mereposisi Kedudukan Janda (Cerai Mati) dalam Hukum Waris Adat Batak dalam Perspektif Gender}

\section{a. Pengertian Gender}

Persoalan gender bukanlah persoalan baru dalam kajian-kajian sosial, hukum, keagamaan, maupun yang lainnya. Namun demikian, kajian tentang gender masih tetap aktual dan menarik, mengingat masih banyaknya masyarakat khususnya di Indonesia yang belum memahami persoalan ini dan masih banyak terjadi berbagai ketimpangan dalam penerapan gender sehingga memunculkan terjadinya ketidakadilan gender. Pentingnya pengertian gender diberikan dalam pembahasan ini untuk membantu dalam menentukan secara jelas batas-batas yang dimaksud oleh pengertian tersebut, sehingga diperoleh kesamaan cara pandang.

Gender sering diidentikkan dengan jenis kelamin (sex), padahal gender berbeda dengan jenis kelamin. Gender sering juga dipahami sebagai pemberian dari Tuhan atau kodrat Ilahi, padahal gender tidak semata-mata demikian. Secara etimologis kata 'gender' berasal dari bahasa Inggris yang berarti 'jenis kelamin'. ${ }^{28}$ Kata 'gender' bisa diartikan sebagai 'perbedaan yang tampak antara lakilaki dan perempuan dalam hal nilai dan perilaku. $^{29}$

Secara terminologis, 'gender' bisa didefinisikan sebagai harapan-harapan budaya terhadap laki-laki dan perempuan ${ }^{30}$. Definisi lain tentang gender dikemukakan oleh Elaine Showalter. Menurutnya, 'gender' adalah pembedaan laki-laki dan perempuan dilihat

28 John M. Echols, dan Hassan Shadily, Kamus Inggris Indonesia, Gramedia Cet. XII, Jakarta,1983, hlm.,265.

${ }^{29}$ Victoria Neufeldt (ed.), Webster's New World Dictionary, Webster's New World Clevenland, New York,1984, hlm.,561.

30 Hilary M. Lips, Sex and Gender: An Introduction, Myfield Publishing Company, London,1993, hlm.,4. 
dari konstruksi sosial budaya ${ }^{31}$. Gender bisa juga dijadikan sebagai konsep analisis yang dapat digunakan untuk menjelaskan sesuatu ${ }^{32}$. Lebih tegas lagi disebutkan dalam Women's Studies Encyclopedia bahwa gender adalah suatu konsep kultural yang dipakai untuk membedakan peran, perilaku, mentalitas, dan karakteristik emosional antara laki-laki dan perempuan yang berkembang dalam masyarakat ${ }^{33}$.

Dari beberapa definisi tersebut dapat dipahami bahwa gender adalah suatu sifat yang dijadikan dasar untuk mengidentifikasi perbedaan antara laki-laki dan perempuan dilihat dari segi kondisi sosial dan budaya, nilai dan perilaku, mentalitas, dan emosi, serta faktor-faktor nonbiologis lainnya. Gender berbeda dengan sex, meskipun secara etimologis artinya sama sama dengan sex, yaitu jenis kelamin $^{34}$. Secara umum sex digunakan untuk mengidentifikasi perbedaan laki-laki dan perempuan dari segi anatomi biologis, sedang gender lebih banyak berkonsentrasi kepada aspek sosial, budaya, dan aspek-aspek nonbiologis lainnya. Kalau studi sex lebih menekankan kepada perkembangan aspek biologis dan komposisi kimia dalam tubuh seorang laki-laki dan seorang perempuan, maka studi gender lebih menekankan kepada perkembangan aspek maskulinitas dan femininitas seseorang.

Sejarah perbedaan gender antara seorang pria dengan seorang wanita terjadi melalui proses yang sangat panjang dan dibentuk oleh beberapa sebab, seperti kondisi sosial budaya, kondisi keagamaan, dan kondisi kenegaraan. Dengan proses yang panjang ini, perbedaan gender akhirnya sering dianggap menjadi ketentuan Tuhan yang bersifat kodrati atau seolah-olah bersifat biologis yang tidak dapat diubah lagi. Inilah sebenarnya yang menyebabkan awal terjadinya ketidakadilan gender di tengah-tengah masyarakat.

Gender memiliki kedudukan yang penting dalam kehidupan seseorang dan dapat menentukan pengalaman hidup yang akan ditempuhnya. Gender dapat menentukan akses

31 Elaine Showalter (ed.), Speaking of Gender, Routledge, New York and London, 1989, hlm.,3.

32 Nasaruddin Umar, Argumen Kesetaraan Jender: Perspektif Al-Qur'an, Paramadina. Cet. I, Jakarta, 1999, hlm.,34.

33 Siti Musdah Mulia, Islam Menggugat Poligami, Gradedia Pustaka Utama. Cet. I, Jakarta, 2004, hlm.,4

${ }^{34}$ Echols, dan Shadily, op.cit., hlm.,517. seseorang terhadap pendidikan, dunia kerja, dan sektor-sektor publik lainnya. Gender juga dapat menentukan kesehatan, harapan hidup, dan kebebasan gerak seseorang. Jelasnya, gender akan menentukan seksualitas, hubungan, dan kemampuan seseorang untuk membuat keputusan dan bertindak secara otonom. Akhirnya, genderlah yang banyak menentukan seseorang akan menjadi apa nantinya.

b. Kedudukan Janda (Cerai Mati) dalam Hukum Waris Adat Batak dalam Perspektif Gender

Sejumlah kajian mengenai perempuan dan hukum di Indonesia menyimpulkan betapa marginalnya posisi perempuan. Hal ini membuktikan ketimpangan gender dalam relasi laki-laki dan perempuan di Indonesia masih sangat kuat. Seperti terlihat dalam sistem pewarisan masyarat adat Batak yang menganut sistem patrilineal, dimana perempuan tidak memperoleh warisan harta dan secara ekonomi tergantung pada laki-laki.

Sebagaimana diketahui, bahwa masalah gender sudah sering diwacanakan dan dibahas oleh pemerhati masalah gender dalam berbagai pertemuan-pertemuan, diskusidiskusi, seminar-seminar dan lain-lainnya baik pada tingkat lokal, maupun pada tingkat nasional bahkan pada tingkat internasional. Mansour Fakih, mengemukakan bahwa gender adalah hubungan laki-laki dan perempuan secara sosial. Hubungan sosial antara laki-laki dan perempuan dalam pergaulan hidup seharihari, dibentuk dan diubah oleh masyarakat sendiri, oleh karena itu, sifatnya dinamis, artinya dapat berubah dari waktu kewaktu, dan dapat pula berbeda dari tempat yang satu dengan tempat yang lainnya sejalan dengan kebudayaan masyarakat masing-masing. ${ }^{35}$

Hubungan sosial antara laki-laki dan perempuan dapat dilihat dalam berbagai bidang kehidupan antara lain dalam bidang politik, sosial, ekonomi, budaya dan hukum (baik hukum tertulis maupun tidak tertulis yakni hukum hukum adat). Hubungan sosial antara laki-laki dan perempuan dalam berbagai bidang kehidupan tersebut pada umumnya menunjukkan hubungan yang subordinasi yang artinya bahwa kedudukan perempuan lebih rendah bila dibandingkan dengan kedudukan laki-laki.

35 Mansour Fakih, Analisis Gender \& Transformasi Sosial, Pustaka Pelajar, Yogyakarta, 1996, hlm.,8. 
Hubungan yang sub-ordinasi tersebut dialami oleh kaum perempuan di seluruh dunia karena hubungan yang sub-ordinasi tidak saja dialami oleh masyarakat yang sedang berkembang seperti masyarakat Indonesia, namun juga dialami oleh masyarakat negara-negara yang sudah maju seperti Amerika Serikat dan lain-lainnya. Keadaan yang demikian tersebut dikarenakan adanya pengaruh dari idiologi patriarki yakni idiologi yang menempatkan kekuasaan pada tangan laki-laki dan ini terdapat di seluruh dunia. Keadaan seperti ini sudah mulai mendapat perlawanan dari kaum feminis, karena kaum feminis selama ini selalu berada pada situasi dan keadaan yang tertindas. Oleh sebab itu, kaum feminis berjuang untuk menuntut kedudukan yang sama dengan kaum laki-laki dalam berbagai bidang kehidupan agar terhindar dari keadaan yang sub-ordinasi tersebut.

Dalam bidang hukum adat, khususnya dalam hukum kewarisan dimana Hazairin, sudah pernah menggagas untuk membentuk hukum adat waris nasional yang bersifat bilateral $^{36}$. Demikian juga ada gagasan dalam seminar hukum adat di Yogyakarta tahun 1975 untuk membentuk hukum kekeluargaan nasional yang parental, akan tetapi sampai sekarang gagasan tersebut belum terwujud. Oleh sebab itu, di Indonesia masih berlaku hukum adat waris yang beraneka ragam sesuai dengan sistem kekeluargaan yang dianut oleh masyarakat di Indonesia.

Dalam sistem kekerabatan patrilinial yang dianut oleh masyarakat Batak sangat jelas menempatkan kaum laki-laki pada kedudukan yang lebih tinggi. Laki-laki berkedudukan sebagai ahli waris, sebagai pelanjut nama keluarga, sebagai penerus keturunan, sebagai anggota masyarakat adat dan juga mempunyai peranan dalam pengambilan keputusan keluarga maupun masyarakat luas. Dalam masyarakat yang menganut sistem kekerabatan partilinial kaum perempuan mempunyai kedudukan yang sangat rendah, tidak sebagai ahli waris, tidak sebagai pelanjut keturunan, tidak sebagai penerus nama keluarga karena

36 Menurut Hazairin bahwa sistem hukum kewarisan bilateral adalah sistem kewarisan yang tidak membedakan garis keturunan laki-laki dan perempuan. Keduanya memiliki kekuatan (hak) yang sama untuk mendapatkan harta warisan dari kedua orangtuanya dan kerabatnya. Lihat: Abdul Ghofur Anshori, Hukum Kewarisan Islam di Indonesia, Eksistensi dan Adaptabilitas, Ekonisia Cetakan I, Yogyakarta, 2005, hlm.,93. dalam perkawinan jujur (pada umumnya) perempuan mengikuti suami dan juga tidak menjadi anggota masyarakat adat.

Mencermati tersebut, adalah jelas telah terjadi ketidak adilan hukum dan ketidak adilan gender terhadap perempuan karena perempuan selalu diposisikan pada posisi yang lemah dan sub-ordinasi sehingga tetap terjadi diskriminasi terhadap kaum perempuan. Sebagai solusinya tentu perlu melakukan reposisi kedudukan kaum perempuan dalam bidang hukum adat, termasuk dalam konteks kajian ini adalah mereposisi kedudukan janda (cerai mati) dalam hukum waris adat Batak. Adapun caranya adalah dengan menindaklanjuti apa yang pernah digagas oleh Hazairin, yaitu dengan membentuk hukum adat waris nasional yang bersifat bilateral.

c. Reposisi Kedudukan Janda (Cerai Mati) melalui Pembentukan Hukum Adat Waris Nasional Berdasar Sistem Bilateral

Pembentukan hukum kewarisan nasional berdasarkan sistem bilateral adalah upaya menciptakan sistem hukum kewarisan yang seragam bagi seluruh rakyat yang asas-asas hukumnya diambil atau digali dari asas-asas hukum kewarisan dari ketiga sistem hukum kewarisan yang masih berlaku, yakni hukum kewarisan adat, hukum kewarisan Islam, dan hukum kewarisan KUH Perdata. ${ }^{37}$ Hukum kewarisan Islam yang diperkenalkan Hazairin tersebut, cukup kuat pengaruhnya dalam perkembangan hukum kewarisan Islam di Indonesia yang ditandai oleh lahirnya Kompilasi Hukum Islam (KHI) pada tahun 1991. Pengaruh beliau juga terasa di bidang perkembangan hukum kewarisan adat, terutama melalui jalur yurisprudens $\mathrm{i}^{38}$.

Alasan pertimbangan pembentukan hukum kewarisan dengan sistem bilateral antara lain disebabkan adanya kecenderungan perubahan sistem kekerabatan masyarakat unilateral (patrilineal dan matrilineal) yang mengarah pada kekerabatan parental. Perubahan kecenderungan tersebut mempengaruhi praktik pewarisan masyarakat yang tadinya bersifat satu arah menjadi mengalami perubahan menuju pewarisan bilateral. Alasan

${ }^{37}$ H. S. L. Tobing, "Pengaturan Hukum Waris dalam Sistem Hukum Perdata Nasional", Majalah BPHN, Nomer. 1, Tahun 1989, hlm.,27.

38 Purwoto, S. Gandasubrata, "Perkembangan Hukum Waris Menurut Yurisprudensi", dalam Simposium Hukum Waris Nasional yang diselenggarakan oleh BPHN pada 10-12 Pebruari 1983, Jakarta, hlm., 112 . 
faktor kesetaraan gender, demokratisasi, dan hak asasi manusia turut mempengaruhi perubahan tersebut, baik dari segi sistem kekerabatan masyarakat maupun perubahan pada sistem hukum kewarisannya, di samping faktor pendidikan, agama, dan ekonomi keluarga, bahkan dapat dikatakan bahwa dalam bidang penemuan hukum, dinamika yurisprudensi Mahkamah Agung terhadap kecenderungan dalam menyelesaikan sengketa kewarisan masyarakat sangat kuat mengarah pada sistem bilateral.

Jika ditelaah realitas di lapangan dari ketiga sistem hukum kewarisan yang ada dalam kelompok masyarakat, ternyata telah terjadi penyimpangan dalam praktik pelaksanaan pembagian harta warisan, baik dalam hukum kewarisan menurut KUH Perdata, Islam, dan adat. Itulah sebabnya Rahmadi Usman membuat kesimpulan bahwa kalangan umat Islam dewasa ini seakan-akan tidak lagi melaksanakan hukum kewarisan Islam sebagaimana mestinya. Penyimpangan yang sama juga terjadi pada hukum kewarisan menurut KUH Perdata dan adat, karena harta warisan tidak dibagi sama banyaknya antara bagian ahli waris laki-laki dengan ahli waris perempuan, melainkan lebih didasarkan pada pertimbangan tertentu dari pewaris. Akibatnya, ada ahli waris mendapatkan bagian harta warisan karena dengan pertimbangan untuk permodalan, ada karena untuk pendidikan, atau ada yang dibantu dalam membayar utang melalui harta warisan. Cara-cara pembagian demikian ini diduga kuat dilakukan dengan kesadaran dari pewaris meskipun tidak berdasarkan atas ketentuan hukum kewarisan yang berlaku ${ }^{39}$.

Kodifikasi hukum kewarisan yang bersifat bilateral tersebut sejalan dengan sistem kekeluargaan parental yang umumnya dianut masyarakat. Oleh sebab itu, dalam Pasal 12 huruf F Keputusan Badan Perencana LPHN tertanggal 28 Mei 1962 disebutkan bahwa sistem hukum kewarisan nasional diatur secara bilateral, dan sistem hukum kewarisan seperti ini searah dengan pembangunan hukum kekeluargaan nasional yang bersifat parental. Demikian juga keputusan hasil Seminar Hukum Nasional I tahun 1963 oleh BPHN bahwa, hukum kewarisan untuk seluruh rakyat diatur secara bilateral-individual, dengan kemungkinan

39 Rahmadi Usman, Perkembangan Hukum Perdata dalam Dimensi Sejarah dan Politik Hukum di Indonesia, Pustaka Sinar Harapan, Jakarta, 2003, hlm.,9. adanya variasi dalam sistem bilateral untuk golongan Islam yang memerlukannya. ${ }^{40}$

Selain itu, terdapat juga beberapa seminar nasional yang kemudian menghasilkan naskah akademik peraturan perundang-undangan hukum kewarisan dan rumusan asas-asas hukum kewarisan nasional, di antaranya adalah hasil seminar nasional pada tahun 1987 dan hasil Simposium Hukum Kewarisan Nasional dalam Era Pembangunan oleh BPHN pada tanggal 1- 2 November 1989. Terakhir pada tahun 1995, Kepala Badan Pembinaan Hukum Nasional membentuk tim perumus Naskah Akademik Peraturan Perundang-undangan tentang Hukum Kewarisan, yang kemudian melahirkan Rancangan Undang-undang (RUU) Hukum Kewarisan Nasional Tahun 1995 . $^{41}$

Sistem hukum kewarisan bilateral adalah sistem hukum kewarisan yang tidak mendasarkan ketentuan hukumnya pada sistem kekerabatan unilateral atau berdasarkan klan, melainkan mendasarkan pada masyarakat yang menganut kekerabatan parental. Sistem hukum kewarisan bilateral menempatkan garis kerabat ibu sama kuatnya dengan garis kerabat ayah dalam menghubungkan pewaris dengan ahli waris, sehingga memberi kedudukan yang sama antara ayah dan ibu sebagai pewaris terhadap anak-anaknya baik laki-laki maupun perempuan.

Sistem kodifikasi hukum kewarisan bilateral tersebut nantinya harus bersifat diferensiasi, yakni adanya kesatuan hukum dengan cara merumuskan ketentuan-ketentuan yang bersifat umum dan berlaku bagi semua golongan. Namun di satu sisi, tetap ada ketentuan yang rumusan hukumnya bersifat khusus dan akan berlaku hanya pada golongan tertentu dalam masyarakat. Jadi menyerupai kodifikasi UU Nomer. 1 Tahun 1974 tentang Perkawinan. Di samping itu, kodifikasi hukum kewarisan secara diferensiasi sejalan dengan posisi dan kedudukan bangsa Indonesia yang terdiri dari berbagai suku, agama, dan kepercayaan, serta sistem kekerabatan yang berlaku namun dalam bingkai wawasan nasional.

Dengan demikian, kodifikasi hukum kewarisan secara diferensiasi berperan sebagai sarana pembaruan dalam masyarakat. Fungsi kodifikasi demikian merupakan perwujudan

${ }^{40}$ Rumonda Nasution, Harta Kekayaan Suami Isteri dan Kewarisannya, BPHN, Jakarta, 1992, hlm.,65-75.

${ }^{41}$ Nasution, ibid. 
dari teori Roscoe Pound, di mana hukum berkedudukan sebagai "a tool of social engineering". Juga merupakan manifestasi Teori Friedman mengenai pembangunan sistem hukum. Dengan demikian dapat disimpulkan bahwa kodifikasi hukum kewarisan berdasarkan sistem bilateral dalam konteks mereposisi kedudukan janda (cerai mati) dalam hukum waris adat Batak sudah sangat penting untuk segera direalisasikan .

Dalam konteks kajian ini, setidaknya jika dilihat dari alasan hukum waris adat Batak adalah bahwa hukum waris adat Batak yang menganut sistem masyarakat kebapakan, cenderung menuju ke arah sistem parental dengan mengamati contoh-contoh yang terjadi, misalnya pada masyarakat Batak, di sana lambat laun asas patrilineal yang hampir ditinggalkan menuju kehidupan keluarga yang bilateral sifatnya, yang dari hari ke hari bertambah kuat mengimbangi pengaruh bapak, terlebih bagi masyarakat Batak yang hidup dalam perantauan. Akibatnya, dalam lapangan hukum kewarisan terjadi perubahan (tendensi) ke arah sistem bilateral sehingga anak perempuan ikut mendapat harta karena dinilai dari segi tanggung jawab dan keselamatan (perlindungan) sebagai anggota keluarga yang tidak ada bedanya dengan anak laki-laki.

Begitu pula bagi istri yang ditinggal mati suaminya (cerai mati), maka dipandang sangat tepat jika si ibu yang meneruskan pemeliharaan atas anak-anaknya sampai si anak dewasa, karena dipandang sang ibu akan lebih baik mengurus kepentingan-kepentingan anaknya sendiri daripada siapapun juga. Di dalam meneruskan pemeliharaan ini, sudah tentu ibu (janda), membutuhkan biaya yang tidak sedikit. Oleh sebab itu, sudah sepantasnya kalu ibu (janda) yang mengurus dan menguasai kekayaan si anak yang diperoleh sebagai warisan dari ayahnya yang telah meninggal dunia, selama anak dibawah umur.

Dari fakta-fakta hukum tersebut, dapat disimpulkan bahwa hukum kewarisan adat Batak mengalami perkembangan menuju pada sistem hukum kewarisan bilateral. Di samping itu, sudah menjadi kenyataan bahwa bidang hukum kewarisan yang berlaku di masyarakat mengalami perubahan yang dipicu dari berbagai faktor. Dikemukakan Bushar Muhammad, bahwa: "Atas alasan sosiologis dalam masyarakat, membawa dan mempengaruhi keadaan dan kecenderungan masyarakat Indonesia menuju ke arah sistem bilateral. Keadaannya dipengaruhi dari faktor- faktor pendidikan; perantauan/migrasi dalam arti luas; faktor hidup berdasar sistem keluarga serumah tangga; faktor ekonomi; industrialisasi, teknologi, hidup di kota-kota besar; dan lain-lain"42.

Berbagai faktor pemicu atas perubahan dari sistem kekerabatan yang tadinya mendasarkan diri pada klan lambat laun menjadi lebih terbuka, dan akhirnya mempengaruhi sendi-sendi pokok susunan masyarakat dan sistem kekeluargaan yang berlaku ke arah masyarakat parental. Perubahan secara sosiologis ini, ditandai dengan adanya anggapan bahwa janda bukan lagi barang warisan (levirat) dalam masyarakat patrilineal, disamping itu saat ini telah banyak dilakukannya perkawinan antara suku yang bersifat nasional. ${ }^{43}$

Pembentukan hukum kewarisan nasional berdasarkan sistem bilateral berkaitan dengan langkah legislasi melalui kodifikasi dan unifikasi hukum kewarisan. Dalam referensi dikatakan bahwa kodifikasi dan unifikasi hukum, bukan saja untuk mencapai kepastian hukum, keseragaman hukum serta penyederhanaan hukum. Namun juga sebagai pedoman politik hukum bagi pemerintah dalam menghadapi tugas membina hukum nasional. ${ }^{44}$

\section{A. Simpulan}

Berdasarkan pembahasan di atas, penulis dapat simpulkan beberapa hal sebagai berikut:

a. Kedudukan janda dalam hukum waris adat Batak menurut kaidah adat masyarakat Batak, tidak memberi peluang kepada janda untuk mewarisi harta peninggalan suaminya. Meskipun masyarakat Batak menganut sistem kewarisan individual, dimana dalam sistem ini harta peninggalan akan dibagi kepada ahli waris sesuai dengan bagian masing-masing, tetapi hanya anak lakilaki yang berhak mendapatkan bagian dari harta peninggalan tersebut. Jadi, jelaslah bahwa jika kedudukan janda dikaitkan dengan sistem kewarisan dan prinsip kewarisan, maka dapat dikatakan bahwa janda tidak dapat mewarisi harta

42 Muhammad Bushar, Susunan Hukum Kekeluargaan Indonesia Menuju ke Sistem Bilateral-Parental (Pandangan Sosilogis-Yuridis), PT Pradnya Paraminta Cetakan 1, Jakarta, 2006, hlm.,28.

${ }^{43}$ Bushar, ibid.

${ }^{44}$ R. Subekti, "Beberapa Pemikiran Mengenai Sistem Hukum Nasional yang akan Datang", Majalah BPHN, 1992, hlm.,102. 
peninggalan suaminya, karena janda bukanlah ahli waris dari almarhum suaminya

b. Cara mereposisi kedudukan janda (cerai mati) dalam hukum waris adat Batak agar mempunyai kedudukan yang seimbang dengan ahli waris lainnya (perspektif gender dan prinsip keadilan), yaitu dengan membentuk hukum adat waris nasional yang bersifat bilateral. Pembentukan hukum kewarisan nasional berdasarkan sistem bilateral adalah upaya menciptakan sistem hukum kewarisan yang seragam bagi seluruh rakyat yang asas-asas hukumnya diambil atau digali dari asas-asas hukum kewarisan dari ketiga sistem hukum kewarisan yang masih berlaku, yakni hukum kewarisan adat, hukum kewarisan Islam, dan hukum kewarisan KUH Perdata.

\section{B. Saran}

Implikasi dari hasil penulisan ini adalah pada penyetaraan kedudukan janda (cerai mati) dalam hukum adat waris Batak agar mempunyai kedudukan yang seimbang dengan ahli waris lainnya. Berdasarkan hal tersebut, maka penulis mencoba memberikan saran sebagai berikut:

a. Hendaknya cara mereposisi kedudukan janda (cerai mati) dalam hukum adat waris nasional yang bersifat bilateral, agar memperhatikan kemajemukan masyarakat Indonesia, baik dari segi agama, adat istiadat, dan sistem kekerabatan, serta kemajemukan dari sistem hukum kewarisan itu sendiri, mengingat hukum kewarisan merupakan bidang hukum yang berkaitan erat dengan faktor-faktor tersebut.

b. Pembentukan hukum kewarisan nasional berdasarkan sistem bilateral perlu mengikuti kodifikasi UU Nomer. 1 Tahun 1974, yakni dilakukan secara diferensiasi atau adanya kesatuan hukum dengan cara merumuskan ketentuan-ketentuan yang bersifat umum dan berlaku bagi semua golongan, namun di satu sisi tetap ada ketentuan yang rumusan hukumnya bersifat khusus dan akan berlaku hanya pada golongan tertentu dalam masyarakat.

\section{DAFTAR PUSTAKA}

1. Buku

Abdurrahman. Kompilasi Hukum Islam, Cetakan I. Jakarta: Akademika Presindo, 1992.
Ali, Achmad. Menjelajah Kajian Empiris terhadap Hukum, Cetakan I. Jakarta: Yasrif Watampone, 1996.

Ali, Zainuddin. Pelaksanaan Hukum Waris di Indonesia. Jakarrta: Sinar Grafika, 2008.

Affandi, Ali. Hukum Waris Hukum Kekeluargaan Hukum Pembuktian. Jakarta: Bina Aksara, 1986.

Anshori, Abdul Ghofur. Hukum Kewarisan Islam di Indonesia, Eksistensi dan Adaptabilitas, Cetakan
Yogyakarta: Ekonisia, 2005.

Arikunto, Suharsimi. Prosedur Penelitian Suatu Pendekatan Praktek. Jakarta: Rineka Cipta, 2008.

Busar, Muhammad. Pokok-Pokok Hukum Adat, Cet.3. Jakarta: Pradnya Paramita, 1985.

Bemelen,Sita van dkk. Women and Mediation in Indonesia. Leiden: KITLV Press.(ed).(1992).

$\begin{array}{lr}\text { Kekeluargaan } & \text { Sukuman } \\ \text { Menuju ke Sistem } & \text { Indonesia } \\ \text { Parental (Pandangan Sosilogis- } & \text { Saridis), Cetakan I. Jakarta: PT } \\ \text { Pradnya Paraminta, 2006. }\end{array}$

Charlotte Bunch, Prospect for Global Feminist, dalam: Feminist Framework, Jaggar and Rothenberg, eds.,

Danardono,Donny, Teori Hukum Feminis, dalam buku Perempuan dan Hukum. Menuju Hukum yang Berspektif Kesetaraan dan Keadilan: Jakarta, Yayasan Obor Indonesia,2000.

Echols, John M. dan Hassan Shadily. Kamus Inggris Indonesia. Jakarta: Gramedia. Cet. XII, 1983.

Fajar, Mukti dan Yulianto Achmad, Dualisme Penelitian Hukum Normatif dan Empiris. Yogyakarta: Pustaka Pelajar, Cetakan 1, 2010.

Fakih, Mansour. Analisis Gender \& Transformasi Sosial. Yogyakarta: Pustaka Pelajar, 1996. 
Friedman, Lawrence Meir. American Law: an Introduction, Edisi Kedua, Terj. Wishnu Basuki dengan judul, Hukum Amerika: Sebuah Pengantar, Cetakan I, 2001. Jakarta: PT Tatanusa, 2001.

Gandhi,Mahatma, Kaum Perempuan dan Ketidakadilan Sosial, Yogyakarta: Pustaka Pelajar,2002.

Hadikusuma, Hilman. Pengantar Ilmu Hukum Adat Indonesia. Bandung: Mandar Maju, 2003.

Hukum Waris Adat, Cet,7. Bandung: PT. Citra Aditya Bakti, 2003.

Harahap, M. Yahya. Kedudukan Janda, Duda dan Anak Angkat Dalam Hukum Adat, Cet. 1. Jakarta: Citra Aditya Bakti, 1993.

Irianto, Sulistyowati. Perempuan Diantara Berbagai Pilihan Hukum. Jakarta: Yayasan Obor Indonesia 2003.

Irianto,Sulistyowati, Pendekatan Hukum Berspektif Perempuan, dalam Penghapusan Diskriminasi Terhadap Wanita, Bandung: Alumni,2000.

Jamin, Mohammad, Peradilan Adat; Pergeseran Politik Hukum Perspektif UU Otonomi Khusus Papua, Graha Ilmu,2014.

Koentjaraningrat. Manusia dan Kebudayaan di Indonesia, Cet. 4. Jakarta: Djambatan, 1979.

Lips, Hilary M. Sex and Gender: An Introduction. London: Myfield Publishing Company, 1993.

Marzuki, Peter Mahmud. Penelitian Hukum. Jakarta: Kencana, 2005.

Mulia, Siti Musdah. Islam Menggugat Poligami. Jakarta: Gradedia Pustaka Utama. Cet. I, 2004.

Nasution, Rumonda. Harta Kekayaan Suami Isteri dan Kewarisannya. Jakarta: BPHN, 1992.
Nazir, Moch. Metode Penelitian. Jakarta: Ghalia Indonesia, 2008.

Neufeldt, Victoria (ed.). Webster's New World Dictionary. New York: Webster's New World Clevenland, 1984.

Pitlo, A. Hukum Waris Menurut Kitab Undang-Undang Hukum Perdata Belanda, terj. M. Isa Arief. Jakarta: Intermasa, 1979.

Prodjodikoro, Wirjono. Hukum Warisan di Indonesia, Cet. 5. Bandung: Sumur, 1976.

Putnam Tong,Rosemarie, Feminist Thought, Yogyakarta: Jalasutra, 2008

Rasyidi, Lili dan Ira Thania Rasyidi, Dasardasar Filsafat dan Teori Hukum, Cetakan IX. Bandung: PT Citra Aditya Bakti, 2004.

Rato, Dominikus. Pengantar Hukum Adat. Yogyakarta: Laksbang Pressindo, Yogyakarta, 2009.

Showalter, Elaine (ed.), Speaking of Gender. New York \& London: Routledge, 1989.

Soejono dan H. Abdurahman, Metode Penelitian Hukum. Jakarta: Rineka Cipta, 2003.

Soekanto, Soerjono dan Mustafa Abdullah, Sosiologi Hukum dalam Masyarakat, Cetakan I. Jakarta: , CV Rajawali, 1980.

------------------- dan Yusuf Usman, Kedudukan Janda Dalam Hukum Waris Adat, Cet. 1. Jakarta: Ghalia Indonesia, 1986.

Soepomo, R. Bab-bab tentang Hukum Adat. Jakarta: Penerbit Universitas, 1996. --. Sistem Hukum di Indonesia Sebelum Perang Dunia II, Cetakan XV. Jakarta: PT. Pradnya Paramita, 1997.

Sudiyat, Iman. Hukum Adat Sketsa Asas, Cet, 2. Yogyakarta: Liberty, 1981. 
Suparman, Eman. Intisari Hukum Waris Indonesia. Bandung: Mandar Maju, 1991.

Hukum Waris Indonesia. Bandung: Refika Aditama, 2005.

Sutopo, Heribertus. Pengantar Penelitian Kualitatif. Surakarta: Puslitbang UNS, 2008.

Umar, Nasaruddin. Argumen Kesetaraan Jender: Perspektif Al-Qur'an. Jakarta: Paramadina. Cet. I, 1999.

Usman, Rahmadi. Perkembangan Hukum Perdata dalam Dimensi Sejarah dan Politik Hukum di Indonesia. Jakarta: Pustaka Sinar Harapan, 2003.

Vergouwen, C. Masyarakat dan Hukum Adat Batak Toba. Yogyakarta: PT. LkiS Pelangi Aksara, 2004.

Wignjodipoero, Soerojo. Pengantar dan Azasazas Hukum Adat. Jakarta: Gunung Agung, 1989.

Wiranata, I. Gede Ab. Hukum Adat di Indonesia. Bandung: PT. Citra Aditya Bakti, 2005.

\section{Peraturan Perundang-Undangan}

Undang-Undang Dasar Negara Republik Indonesia Tahun 1945.
Kitab Undang-Undang Hukum Perdata (Burgerlijk Wetboek (BW) Staatsblad Tahun 1847 Nomer 23).

Undang-Undang Nomer. 1 Tahun 1974 tentang Perkawinan.

Undang-Undang Nomer. 7 Tahun 1984

tentang Pengesahan Konvensi Mengenai Penghapusan Segala Bentuk Diskriminasi Terhadap Wanita

Undang-undang Nomer. 39 Tahun 1999 tentang Hak Asasi Manusia

Instruksi Presiden Nomer. 1 Tahun 1991 tentang Kompilasi Hukum Islam.

3. Simposium

Gandasubrata, Purwoto, S. "Perkembangan Hukum Waris Menurut Yurisprudensi", dalam Simposium Hukum Waris Nasional yang diselenggarakan oleh BPHN Jakarta, 10-12 Pebruari 1983.

\section{Majalah}

Subekti, R. "Beberapa Pemikiran Mengenai Sistem Hukum Nasional yang akan Datang", Majalah BPHN, 1992.

Tobing, H. S. L. "Pengaturan Hukum Waris dalam Sistem Hukum Perdata Nasional", Majalah BPHN, No. 1, Tahun 1989. 